\title{
Minor Salivary Gland Small Cell Carcinoma
}

National Cancer Institute

\section{Source}

National Cancer Institute. Minor Salivary Gland Small Cell Carcinoma. NCI Thesaurus.

Code C5956.

An infrequent small cell carcinoma that arises from a minor salivary gland and is characterized by the presence of a high number of mitotic figures. 